\title{
Physico-chemical parameters of Titrigachhi Daha
}

\author{
Damodar Thapa Chhetry $^{1^{*}}$ and Joydeb Pal ${ }^{2}$ \\ ${ }^{1}$ Department of Zoology, Post Graduate Campus, T.U., Biratnagar, Nepal \\ ${ }^{2}$ Department of Zoology, North Bengal University, India \\ *E-mail:thp_damodar@redifmail.com
}

\begin{abstract}
This paper deals with the physico-chemical parameters of the Titrigachhi daha. The maximum air temperature was recorded in rainy season but the water temperature was maximum in summer and lowest in winter season. Transparency, $\mathrm{pH}$, dissolved oxygen, total alkalinity, total hardness were maximum in winter season. Free carbondioxide, chloride and biological oxygen demand were maximum in summer season. The minimum transparency, total alkalinity, total hardness and chloride were recorded in rainy season. Dissolved oxygen and $\mathrm{pH}$, was minimum in summer season. The minimum carbondioxide and BOD were recorded in winter season. Air temperature, water temperature, free carbondioxide, and biological oxygen demand showed positive and significant correlation with each other. Similarly, transparency, $\mathrm{pH}$, dissolved oxygen, total hardness showed positive and significant correlation with each other. Total alkalinity showed positive and significant correlation with chloride.
\end{abstract}

Key words: Physico-chemical parameters, Titrigachhi Daha.

\section{Introduction}

Titrigachhi daha is an oxbow lake, located within the Koshi Tappu Wildlife Reserve. It lies between $26^{\circ} 36^{\prime} 11.7^{\prime} \mathrm{N}$ latitude and $87^{\circ} 00^{\prime} 53.8^{\prime} \mathrm{E}$ longitude. It covers about 3 ha area (Figure 1). It is rich in aquatic plants and animals. Water enters from the Koshi river in monsoon season and remains throughout the year.

Though vast number of limnological investigations have been carried out in other countries, only a few works have been done in Nepal. However, Lohman et al. (1988), McEachern (1994) and Ormerod et al. (1996) have contributed on limnological work.

\section{Materials and Methods}

Physico-chemical parameters of the Titrigachhi daha were studied for two years from July, 2002-June, 2004. The water samples were collected from three sites between 8 am and $11 \mathrm{pm}$, once in every month at regular interval. The air temperature and physico- chemical parameters of water were analysed in the field. However, the BOD test after 5 days incubation in the incubator was done in the laboratory of Post Graduate Campus, Biratnagar. Transparency, air temperature and water temperature were recorded between 12 noon and 1 p.m. Air and water temperatures were recorded by a thermometer and $\mathrm{pH}$ with the help of a $\mathrm{pH}$ meter. The transparency was measured by Secchi disc. Other parameters such as dissolved oxygen, free carbon dioxide, alkalinity, hardness, chloride, and BOD were measured according to APHA (1985). 


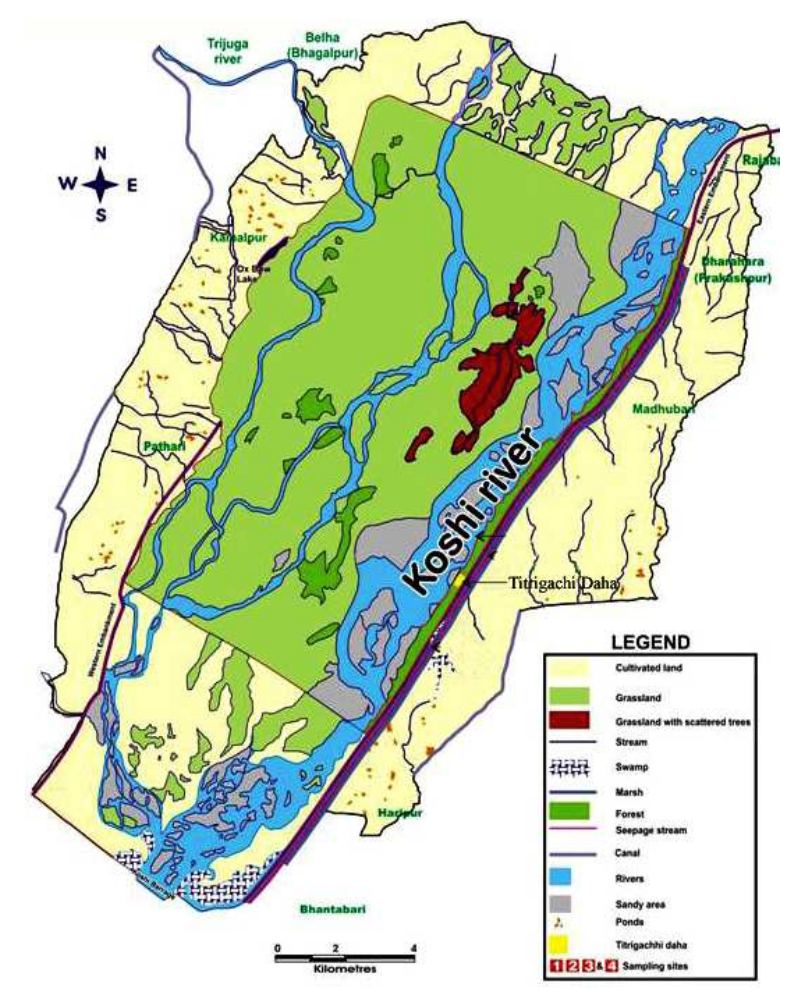

Figure 1. Map showing the location of Titrigachhi Daha in Koshi Tappu Wildlife Reserve.

\section{Results and Discussion}

\section{Air temperature}

The highest air temperature was recorded in May (Table $1 \& 2$ ). When data on monthly air temperature of whole study period (July, 2002-June, 2004) were pooled to seasonal values, the rainy season showed highest air temperature. A gradual increase in air temperature was noticed during summer months in this area. The air temperature showed positive and significant correlation with water temperature $(r=0.9739$, $\mathrm{P}<0.01)$, free carbon dioxide $(\mathrm{r}=0.8488, \mathrm{P}<0.01)$ and with biological oxygen demand $(\mathrm{r}=0.6706, \mathrm{P}<0.01)$ (Table 3). Chakaraboty et al. (1959), Kant and Anand (1978) and Rawat et al. (1995) have also reported strong positive correlation with water temperature.

\section{Water temperature}

Generally, water temperature is influenced by air temperature and intensity of solar radiation. It was highest in summer due to high air temperature and greater light penetration (Table 4). Though air temperature was high in rainy season, water temperature comparatively lower at that time in comparison to that during summer. It might be due to high turbidity, high volume of water and greater velocity of water in rainy season. The water temperature showed positive and significant correlation with free carbon dioxide $(\mathrm{r}=0.9020, \mathrm{P}<0.01)$, biological oxygen demand $(\mathrm{r}=0.7416, \mathrm{P}<$ $0.01)$ but inverse and significant correlation with transparency $(\mathrm{r}=-0.4687, \mathrm{P}<0.05)$, $\mathrm{pH}(\mathrm{r}=-0.7587, \mathrm{P}<0.01)$, dissolved oxygen $(\mathrm{r}=-0.8977, \mathrm{P}<0.01)$, total alkalinity $(\mathrm{r}=-$ 0. 6182, $\mathrm{P}<0.01)$ and total hardness $(\mathrm{r}=-0.6227, \mathrm{P}<0.01)$ (Table 3). Bose and Gorai (1993) reported negative significant correlation between water temperature and dissolved oxygen. Munawar (1970) has observed that shallower the water body more quickly it reacts to the change in the temperature. Chakaraboty et al. (1959), Kant and 
Anand (1978) and Rawat et al. (1995) also obtained strong positive significant correlation with water temperature.

\section{Transparency}

The maximum transparency was recorded in winter followed by summer and rainy season (Table 4). The maximum transparency was in winter due to lesser amount of suspended organic and inorganic materials and absence of rain. Transparency is influenced mainly by suspended organic matter (Green, 1974). Higher transparency during winter months was recorded by Rawat et al. (1995), and Mishra et al. (1999). Minimum transparency recorded in the rainy season may be due to more sand particles and colloidal soil carried by the rain water. Similar trends were observed by Singh (1995), Rawat et al. (1995), and Mishra et al. (1998). McCombie (1953) recorded that the transparency shows a direct relationship with the suspended organism and nonliving particles in the water. Transparency showed positive and significant correlation with $\mathrm{pH}(\mathrm{r}=3869, \mathrm{P}<0.10)$, dissolved oxygen $(\mathrm{r}=0.5565, \mathrm{P}<0.01)$, total alkalinity $(\mathrm{r}=$ 0. 5869, $\mathrm{P}<0.01)$, total hardness $(\mathrm{r}=0.8645, \mathrm{P}<0.01)$, and chloride $(\mathrm{r}=0.6616$, $\mathrm{P}<0.01$ ) (Table 3).

\section{$p H$}

The maximum water $\mathrm{pH}$ was recorded in winter season followed by rainy and summer season (Table 4). The maximum value of $\mathrm{pH}$ in winter season may be attributed to algal blooms because Hutchinson et al. (1929) and Roy (1955) have shown that the higher $\mathrm{pH}$ is associated with the phytoplankton maxima. The minimum $\mathrm{pH}$ recorded in summer may be due to low photosynthesis. The $\mathrm{pH}$ showed positive and significant correlation with dissolved oxygen $(\mathrm{r}=0.7551, \mathrm{P}<0.01)$ and total hardness $(\mathrm{r}=0.4263$, $\mathrm{P}<0.0 .05)$ (Table 3).

\section{Dissolved oxygen}

The dissolved oxygen ranged between $8.27 \mathrm{mg} / 1 \pm 0.254$ to $5.83 \mathrm{mg} / \mathrm{l} \pm 0.226$ during study period. Seasonally, maximum dissolved oxygen was recorded in winter followed by rainy and summer season. It may be due to low temperature. Similar observations were made by Moitra and Bhattacharya (1966). The minimum dissolved oxygen was found in summer due to high temperature, higher microbial demand for oxygen in decomposition of organic matter (Bhowmick \& Singh, 1985). The dissolved oxygen showed positive and significant correlation with total alkalinity $(\mathrm{r}=0.4866, \mathrm{P}<0.05)$, and total hardness $(\mathrm{r}=0.5481, \mathrm{P}<0.01)$ but inverse and significant correlation with free carbon dioxide $(\mathrm{r}=-0.871, \mathrm{P}<0.01)$ and biological oxygen demand $(\mathrm{r}=-0.8076$, $\mathrm{P}<0.01$ ) (Table 3).

\section{Free Carbon dioxide}

The maximum free carbon dioxide was recorded in April. It may be due to high temperature, high rate of decomposition of organic matter, low volume of water etc. Michael (1969) stated that the concentration of carbon dioxide is directly correlated with the amount and nature of biological activity in water. Free carbon dioxide of water showed positive and significant correlation with water temperature and biological oxygen demand and inverse and significant correlation with dissolved oxygen. Pahwa and Mahrotra (1966) observed inverse correlation of free $\mathrm{CO}_{2}$ with dissolved oxygen.

\section{Total alkalinity}


The total alkalinity was maximum in January and minimum in September (Tables 1 \& 2). The maximum total alkalinity was found in winter season followed by summer and rainy season (Table 4). Chakraborty et al. (1959) and Mishra et al. (1998) reported maximum total alkalinity during winter. Water bodies having alkalinity from 40 to 90 $\mathrm{mg} / \mathrm{l}$ is considered as medium productive and above $90 \mathrm{mg} / \mathrm{l}$ as highly productive (Jhingran, 1991). This investigation showed that the study area is suitable for aquatic production. Total alkalinity showed positive and significant correlation with total hardness and chloride (Table 3). Barat and Jha (2002) also reported positive and significant correlation of total alkalinity with hardness

\section{Total hardness}

The maximum value of total hardness was recorded in March and minimum in July (Tables $1 \& 2$ ). The maximum total hardness was recorded in winter followed by summer and rainy season (Table 4). Similar results were obtained by Misra et al. (1999). Minimum quantity in rainy season may be due to more dilution of water (Patralekh, 1994). Ruttner (1953) also recorded similar relationship. It showed positive and significant correlation with total alkalinity and chloride (Table 3 ).

\section{Chloride}

The maximum chloride was recorded in March and minimum in July during study period (Tables 1 \& 2). The maximum chloride content was recorded in summer followed by winter and rainy season (Table 4). The maximum quantity recorded in summer season might be due to low volume of water, high temperature, and high rate of decomposition of organic matters. Chloride concentration indicates the presence of organic waste of animal origin (Thresh et al., 1949). Munawar (1970) suggested that higher concentration of chloride in water is an index of pollution of animal origin and there is a direct relation between chloride concentration and pollution level. Chloride showed positive correlation with biological oxygen demand.

\section{Biological oxygen demand}

The maximum biological oxygen demand was in May and minimum in January (Tables $1 \& 2$ ). Seasonally the maximum value of BOD was recorded in summer followed by rainy and winter season (Table 4). The maximum value obtained in summer may be due to low volume of water and high content of organic matter and minimum value obtained in winter may be due to low temperature and retarded bacterial activity for the decomposition of organic matters. Similar observations were also made by Singh (1995). Ray and Devid (1966) opined that high BOD value indicates organic waste pollution. BOD showed positive and significant correlation with air temperature, water temperature and free $\mathrm{CO}_{2}$ and inverse and significant correlation with $\mathrm{pH}$ and dissolved oxygen. Ray and David (1966) also reported inverse correlation of BOD with dissolved oxygen.

Table 1. Air temperature and physico-chemical parameters of water of Titrigachhi Daha from July, 2002 - June, 2003. (mean \pm SD, N = 9)

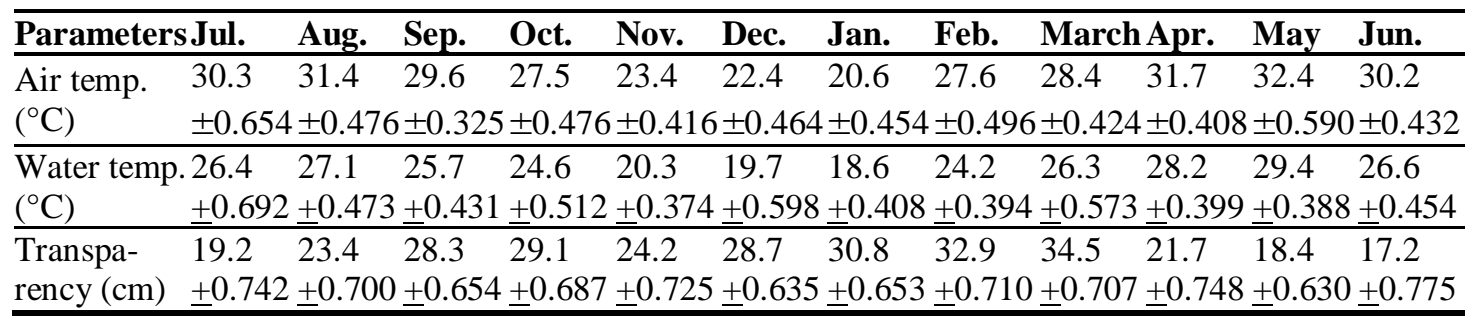




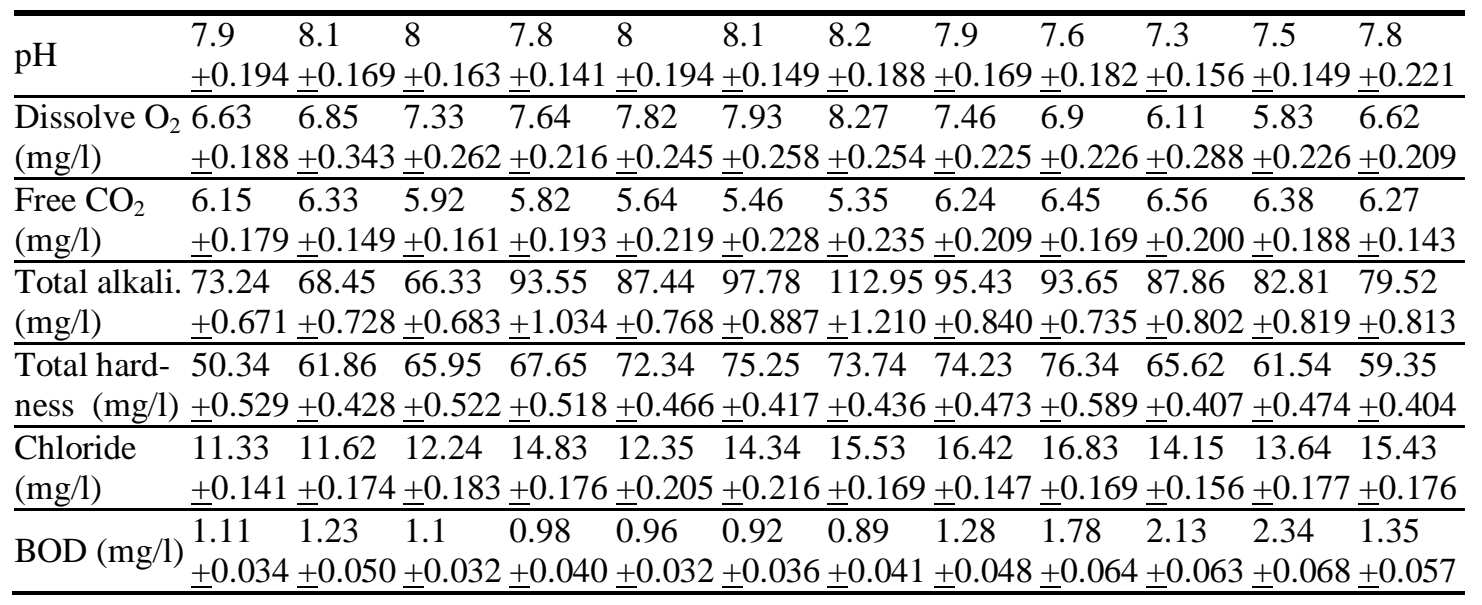

Table 2. Air temperature and physico-chemical parameters of water of Titrigachhi daha from July, 2003 - June, 2004. (mean \pm SD, N = 9)

\begin{tabular}{lllllllllll}
\hline Parameters Jul. & Aug. & Sep. & Oct. & Nov. & Dec. & Jan. & Feb. & March Apr. & May & Jun.
\end{tabular} \begin{tabular}{lllllllllllll}
\hline Air temp. & 30.2 & 32.6 & 29.9 & 27.4 & 24.3 & 22.7 & 21.6 & 26.4 & 29.6 & 32.4 & 33.1 & 31.3
\end{tabular} $\left({ }^{\circ} \mathrm{c}\right) \quad \pm 0.457 \pm 0.429 \pm 0.388 \pm 0.480 \pm 0.426 \pm 0.429 \pm 0.454 \pm 0.410 \pm 0.447 \pm 0.388 \pm 0.424 \pm 0.480$ \begin{tabular}{llllllllllll}
\hline Water temp. 27.3 & 27.7 & 24.8 & 24.6 & 19.3 & 19.6 & 18.2 & 24.2 & 27.3 & 29.1 & 29.2 & 27.2
\end{tabular} $\left({ }^{\circ} \mathrm{c}\right) \quad+0.520 \pm 0.533 \pm 0.565 \pm 0.516 \pm 0.437+0.418+0.483 \pm 0.483 \pm 0.471 \pm 0.416 \pm 0.408 \pm 0.457$ \begin{tabular}{lllllllllllll}
\hline Transpa- & 20.4 & 24.3 & 27.4 & 30.7 & 25.4 & 29.6 & 31.4 & 34.5 & 34.2 & 24.4 & 19.6 & 19.4
\end{tabular}

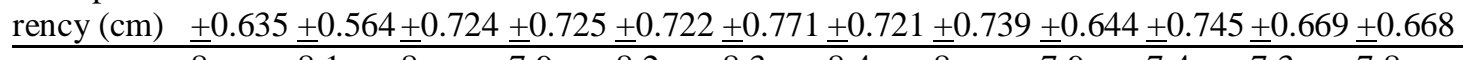

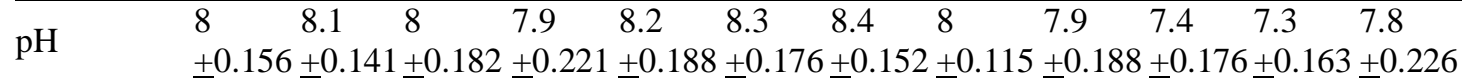

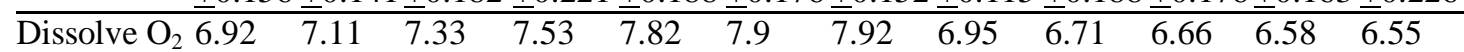
$(\mathrm{mg} / \mathrm{L}) \quad \pm 0.246 \pm 0.134 \pm 0.210 \pm 0.209 \pm 0.229 \pm 0.188 \pm 0.249 \pm 0.262 \pm 0.233 \pm 0.235 \pm 0.265 \pm 0.244$ \begin{tabular}{lllllllllllll}
\hline Free $\mathrm{CO}_{2}$ & 6.13 & 6.24 & 5.92 & 5.75 & 5.55 & 5.42 & 5.23 & 6.35 & 6.56 & 6.62 & 6.25 & 6.15
\end{tabular} $(\mathrm{mg} / \mathrm{l}) \quad+0.188+0.153 \pm 0.180 \pm 0.176 \pm 0.208+0.159 \pm 0.224 \pm 0.191 \pm 0.225 \pm 0.185 \pm 0.149 \pm 0.156$

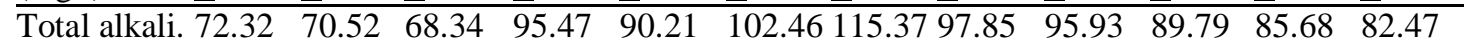
$(\mathrm{mg} / \mathrm{l}) \quad \pm 0.816 \pm 0.845 \pm 0.758 \pm 0.847 \pm 0.954 \pm 1.189 \pm 1.191 \pm 0.779 \pm 0.871 \pm 0.725 \pm 0.761 \pm 0.806$ \begin{tabular}{lllllllllllll}
\hline Total hard- & 53.89 & 63.43 & 67.67 & 68.58 & 75.73 & 77.34 & 79.22 & 81.36 & 83.45 & 61.67 & 56.46 & 55.37
\end{tabular} ness $(\mathrm{mg} / \mathrm{l}) \pm 0.678+0.589 \pm 0.593 \pm 0.585 \pm 0.442 \pm 0.464 \pm 0.550 \pm 0.496 \pm 0.584 \pm 0.595 \pm 0.612 \pm 0.442$ \begin{tabular}{lllllllllllll}
\hline Chloride & 11.23 & 12.24 & 12.25 & 15.73 & 13.47 & 15.23 & 17.32 & 17.56 & 18.14 & 15.57 & 14.34 & 13.45
\end{tabular}

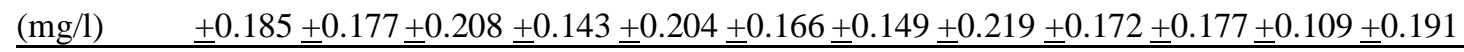

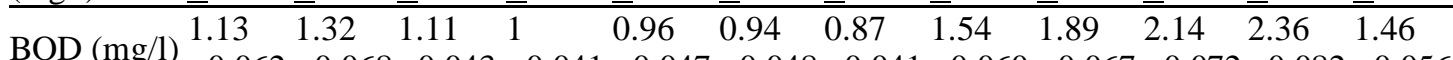
BOD $(\mathrm{mg} / \mathrm{l})+0.062+0.068+0.043+0.041+0.047+0.048+0.041+0.060+0.067+0.072+0.082+0.056$

Table 3. Pearson's Correlation Coefficient (r) for air temperature and physico- chemical parameters of water of Titrigachhi daha from July, $2002-$ June, 2004. $(\mathrm{N}=24$, d.f. $=$ $22)$; Significant at $1 \%$ level $(\mathrm{P}<0.01)$, ** significant at 5\% level $(\mathrm{P}<0.05)$, *** significant at $10 \%$ level $(\mathrm{P}<0.10)$; Values not marked denote non-significant correlation.

\begin{tabular}{|c|c|c|c|c|c|c|c|c|c|}
\hline Correlation & $\begin{array}{l}\text { Water } \\
\text { temp. }\left({ }^{\circ} \mathrm{C}\right)\end{array}$ & $\begin{array}{l}\text { Transpar } \\
\text {-ency } \\
(\mathrm{cm})\end{array}$ & pH & $\begin{array}{l}\text { Dissolve } \mathrm{O}_{2} \\
(\mathrm{mg} / \mathrm{l})\end{array}$ & ${ }_{2}$ Free $\mathrm{CO}_{2}$ & $\begin{array}{l}\text { 2 Total alkali- } \\
\text { nity (mg/l) }\end{array}$ & $\begin{array}{l}\text { - Total hard- } \\
\text { ness (mg/l) }\end{array}$ & $\begin{array}{l}\text { Chlorid } \\
\text { e (mg/l) }\end{array}$ & $\begin{array}{l}\text { BOD } \\
(\mathrm{mg} / \mathrm{l})\end{array}$ \\
\hline $\begin{array}{l}\text { Air temp. } \\
\left({ }^{\circ} \mathrm{C}\right)\end{array}$ & $0.9739 *$ & $-0.5496^{*}$ & $-0.6927 *$ & $-0.8657 *$ & $0.8488^{*}$ & $-0.7234^{*}$ & $-0.6808 *$ & -0.3283 & $0.6706^{*}$ \\
\hline $\begin{array}{l}\text { Water temp. } \\
\left({ }^{\circ} \mathrm{C}\right)\end{array}$ & & $-0.4687 * *$ & $-0.7587^{*}$ & $-0.8977 *$ & $0.9020 *$ & $-0.6182^{*}$ & $-0.6227^{*}$ & -0.1996 & $0.7416^{*}$ \\
\hline $\begin{array}{l}\text { Transpa- } \\
\text { rency }(\mathrm{cm}) .\end{array}$ & & & $0.3869 * * *$ & $0.5565^{*}$ & -0.2529 & $0.5869 *$ & $0.8645^{*}$ & $0.6616^{*}$ & -0.2581 \\
\hline $\mathrm{pH}$ & & & & $0.7551^{*}$ & $-0.7260^{*}$ & 0.2097 & $0.4263^{* *}$ & -0.0474 & $-0.8574 *$ \\
\hline $\begin{array}{l}\begin{array}{l}\text { Dissolve } \mathrm{O}_{2} \\
(\mathrm{mg} / \mathrm{l})\end{array}\end{array}$ & & & & & $-0.871 *$ & $0.4866^{* *}$ & $0.5481 *$ & 0.1262 & $-0.8076^{*}$ \\
\hline
\end{tabular}




\begin{tabular}{|c|c|c|c|c|}
\hline $\begin{array}{l}\begin{array}{l}\text { Free } \mathrm{CO}_{2} \\
(\mathrm{mg} / \mathrm{l})\end{array} \\
\end{array}$ & $-0.4551 * *$ & $-0.3472 * * *$ & 0.0285 & $0.7852 *$ \\
\hline $\begin{array}{l}\text { Total alkali- } \\
\text { nity }(\mathrm{mg} / \mathrm{l})\end{array}$ & & $0.6862 *$ & $0.7877 *$ & -0.1180 \\
\hline $\begin{array}{l}\text { Total hard- } \\
\text { ness }(\mathrm{mg} / \mathrm{l})\end{array}$ & & & $0.6871 *$ & -0.20307 \\
\hline $\begin{array}{l}\text { Chloride } \\
(\mathrm{mg} / \mathrm{l})\end{array}$ & & & & 0.2074 \\
\hline
\end{tabular}

Table 4. Seasonal variation of air temperature and physico-chemical parameters of water of Titrigachhi daha during first year (July, 2002 - June, 2003) and second year (July, 2002 - June, 2004) study period.

\begin{tabular}{lcccccc}
\hline \multirow{2}{*}{ Parameters } & \multicolumn{3}{c}{ Year I } & \multicolumn{3}{c}{ Year II } \\
\cline { 2 - 7 } & Summer & Rainy & Winter & summer & Rainy & Winter \\
\hline Air temperature $\left({ }^{\circ} \mathrm{C}\right)$ & 30.03 & 30.38 & 23.48 & 30.38 & 31 & 24 \\
Water temperature $\left({ }^{\circ} \mathrm{C}\right)$ & 27.03 & 26.45 & 20.8 & 27.45 & 26.75 & 20.43 \\
Transparency $(\mathrm{cm})$. & 26.88 & 22.03 & 28.2 & 28.18 & 22.88 & 29.28 \\
$\mathrm{pH}$ & 7.58 & 7.95 & 8.03 & 7.65 & 7.98 & 8.2 \\
$\mathrm{Dissolved} \mathrm{O}_{2}(\mathrm{mg} / \mathrm{l})$ & 6.58 & 6.86 & 7.92 & 6.73 & 6.98 & 7.79 \\
Free $\mathrm{CO}_{2}(\mathrm{mg} / \mathrm{l})$ & 6.41 & 6.17 & 5.57 & 6.45 & 6.11 & 5.49 \\
Total alkalinity $(\mathrm{mg} / \mathrm{l})$ & 89.94 & 71.89 & 97.93 & 92.31 & 73.41 & 100.88 \\
Total hardness $(\mathrm{mg} / \mathrm{l})$ & 69.43 & 59.38 & 72.25 & 70.74 & 60.09 & 75.22 \\
Chloride $(\mathrm{mg} / \mathrm{l})$ & 15.26 & 12.66 & 14.26 & 16.40 & 12.2 & 15.44 \\
BOD $(\mathrm{mg} / \mathrm{l})$ & 1.88 & 1.20 & 0.94 & 1.98 & 1.26 & 0.94 \\
\hline
\end{tabular}

\section{Acknowledgement}

We are thankful to Prof. Dr. S. Jha, Head, Department of Botany, P.G. Campus for his kind co-operation during manuscript preparation. We also thank Dr. B.R. Subba, Department of Zoology, P.G. Campus for field work as well as providing valuable literature. Thanks are also due to University Grants Commission, Nepal for the financial assistance.

\section{References}

APHA. 1998. Standard Methods for Examination of Water and Waste Water. $20^{\text {th }}$ Edition. Washington, USA.

Barat, S. \& P. Jha. 2002. Changes in the water quality and total Coliform bacterial load in a stretch of river Mahananda at Siliguri city, West Bengal. Asian J. of Microbiol. Biotech. Env. Sc. 4: 571-575.

Bhowmick, B.N. \& A.S. Singh. 1985. Effect of sewage on physico-chemical characteristics and bacterial population in river Ganga at Patna. Ind. J. Ecol. 12: 141-146.

Bose, S.K. \& A.C. Gorai. 1993. Seasonal fluctuation of plankton in relation to physicochemical parameters of a freshwater tank of Dhanbad, India. J. Freshwater Biol. 5: 133-140.

Chakaraborty, R., D.P. Roy \& S.B. Singh. 1959. A quantitative study of the plankton and physico-chemical conditions of the river Jamuna at Allahabad in 1954-55. Ind. J. Fish. 6: 186-203.

Green, J.D. 1974. Ecological studies on crater lakes in west Cameroon, Debunsha Lake. Journal of Zoology 17: 199-223. 
Hutchinson, A.H., S.C. Zucas \& M. McPhail. 1929. Seasonal variation in the chemicals and physical properties of the waters of the Strait of Georgia in relation to phytoplankton. Trans. Roy. Soc., Canada. 3: 177-183.

Jhingran, V.G. 1991. Fish and fisheries of India, $3^{\text {rd }}$ edition. Hindustan Publ. Corp., New Delhi.

Kant, S. \& V.K. Anand. 1978. Interrelationship of phytoplankton and physical factors in Ansar lake, Jammu, India. J. Ecology 5: 134-140.

Lohman, K., J.R. Jones, M.F. Knowlton, D.G. Swar, M.A. Pamperl \& B.J. Brazos. 1988. Pre and post monsoon limnological characteristics of lakes in the Pokhara and Kathmandu valleys, Nepal. Verh. Internat. Verin. Limnol. 23: 558-565.

McCombie, A.M. 1953. Factors influencing the growth of phytoplankton. J. Fish. Res. Biol. 10: 253-282.

McEachern, P. 1994. Limnology and the natural wetlands survey. In: Safeguarding Wetlands in Nepal (Eds. B. Bhandari, T.B. Shrestha \& P. McEachern), IUCN, Nepal. pp. 89-103.

Michael, R.G. 1969. Seasonal trends in physico-chemical factors and plankton of a freshwater fish pond and their role in fish culture. Hydrobiol. 33: 144-160.

Mishra, A.P., B.K. Bora \& M. Sharma 1998. Investigations on the seasonal variation of certain Physico-chemical parameters of a Beel, Assam, India. J. Freshwater Biol. 10: $83-87$.

Mishra, A.P., B.K. Bora \& M. Sharma. 1999. Limnological investigation of a freshwater tributary Assam, India. J. Freshwater Biol. 11: 1-5.

Moitra, S.K. \& B.K. Bhattacharya. 1996. Some hydrobiological factors affecting plankton production in fish pond at Kalyani, W.B., India. Icthyologia 4: 8-12.

Munawar, M. 1970. Limnological studies of fresh water ponds of Hyderabad, India-I. The Biotope. Hydrobiologia. 35: 127-162.

Ormerod, S.J., S.T. Buckton, P.A. Brewin, A. Jenkins, R.C. Johnson, U. Juttner \& A. Suren. 1996. Biodiversity, chemistry and structure in streams of the Nepalese Himalaya. In: Proc. Inter. Confer. Ecohydrol. High Mount. (Eds. S.R. Chalise \& N.R. Khanal), ICIMOD, Kathmandu. pp. 1197-200.

Pahwa, D.V. \& S.N. Mehrotra. 1966. Observations on fluctuaions in abundance of plankton in relation to certain hydrobiological conditions of river Ganga. Proc. Nat. Acad. Sci. 36B(2): 57-189.

Patralekh, L.N. 1994. Comparative account of physico-chemical properties of three freshwater ecosystems. J. Freshwater Biol. 6: 115-119.

Rawat, M.S., C.P. Juyal \& R.C. Sharma. 1995. Morphometry and physico-chemical profile of high altitude lake Deoria Tal of Garwal Himalaya. J. Freshwater Biol. 7: $1-6$.

Ray, P. \& A. David. 1966. Effect of industrial wastes and sewage upon the chemical and biological composition and fisheries of the river Ganga at Kanpur. Environ. Hlth. 8: $307-339$.

Roy, H. 1955. Plankton ecology of river Hooghly, West Bengal. Ecology 36: 169-744.

Ruttner, F. 1953. Fundamentals of Limnology. University of Toronto Press, Toronto.

Singh, M. 1995. Impact of human activities on the physico-chemical conditions of two fish ponds at Patna, India. J. Freshwater Biol. 7:13-17.

Thresh, J.C., J.F. Beale \& E.V. Suckling. 1949. The examination of water and water supplies, (Ed. E.W. Taylor), J. \& A. Churchill Ltd., London. 